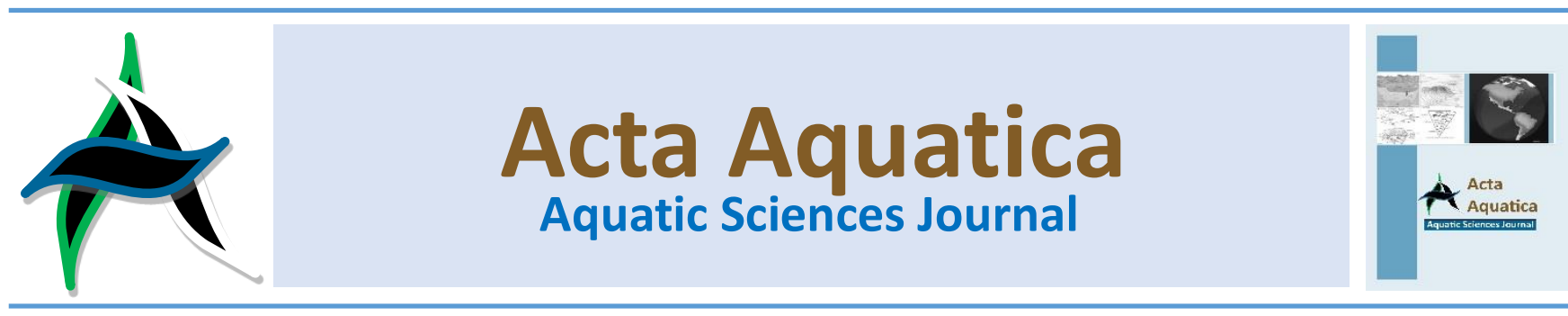

\title{
Kelimpahan dan pola sebaran gastropoda di Pantai Blebak Jepara
}

\section{Abundance and distribution pattern of gastropods in Blebak Beach Jepara}

\author{
Desti Setiyowati $^{\text {a, * }}$ \\ a Program Studi Budidaya Perairan, Fakultas Sains dan Teknologi, Universitas Islam Nahdlatul Ulama, Jepara
}

\begin{abstract}
Abstrak
Tujuan dari penelitian ini adalah untuk mengetahui karakteristik, kelimpahan dan pola sebaran gastropoda di Pantai Blebak Jepara. Penelitian ini berlokasi di Pantai Blebak, Desa Sekuro Kabupaten Jepara. Teknik pengambilan sampel adalah purposive sampling. Sampel diambil dari 3 stasiun. Masing-masing stasiun dibuat garis transek sepanjang $30 \mathrm{~m}$ dengan jarak antar transek $10 \mathrm{~m}$. Setiap transek terdiri dari 3 plot dengan ukuran $1 \times 1 \mathrm{~m}$. Pengambilan sampel Gastropoda dilakukan pada saat surut dan tidak hujan. Gastropoda yang diambil adalah gastropoda yang terdapat pada setiap plot kuadrat dan di dalam substrat sampai kedalaman $5 \mathrm{~cm}$. Karakteristik gastropoda di Pantai Blebak Jepara ditemukan 4 famili dari 7 spesies gastropoda:Cerithidea cingulata, Cerithidea qudrata, Terebralis sulcata, Chicoreus capucinus, Littoraria scabra, Littoraria melanostoma, dan Volema paradisiaca.Cerithidea qudratamenunjukkan nilai kelimpahan tertinggi $\left(12,33 \mathrm{ind} / \mathrm{m}^{2}\right)$. Pola sebaran Gastropoda di Pantai Blebak Jepara pada umumnya menyebar secara merata.
\end{abstract}

Kata kunci: pola distribusi; kelimpahan; gastropoda

\begin{abstract}
Coastal waters Blebak Jepara has the potential of mangrove ecosystems that are good for mangrove conservation area management. However, land cleared for shrimp farming (aquaculture), fishing activities and attractions makes the mangrove in coastal waters be on the wane, so we need a scientific study to determine whether the abundance and distribution patterns of gastropods in those areas are still good or otherwise. The purpose of this study was to determine the characteristics, abundance and distribution patterns of gastropod in coastal waters Blebak Jepara. The research was conducted in coastal waters Blebak Jepara from June to October 2016. The sampling technique is purposive sampling. Characteristics gastropods in coastal waters Blebak Jepara found 4 familly of seven species of gastropods: Cerithidea cingulata, Cerithidea qudrata, Terebralis sulcata, Chicoreus capucinus, Littoraria scabra, Littoraria melanostoma, and Volema paradisiaca. Cerithidea qudrata showed the highest abundance values (12.33 individuals $\left./ \mathrm{m}^{2}\right)$. Gastropoda distribution patterns in coastal waters Blebak Jepara generally spread evenly.
\end{abstract}

Keywords: distribution pattern; abundance; gastropods

\footnotetext{
* Korespondensi: Program Studi Budidaya Perairan, Fakultas Sains dan Teknologi, Universitas Islam Nahdlatul Ulama Jepara, Jl. Taman Siswa (Pekeng) Tahunan Jepara. Kode Pos 59427, Indonesia.

e-mail:desti.8@unisnu.ac.id

doi: https://doi.org/10.29103/aa.v5i1.655
}

\section{Pendahuluan}

Kabupaten Jepara termasuk ke dalam wilayah Propinsi Jawa Tengah, yang secara astronomis terletak antara 54'20,67" - 6ㄴ7'25,83" LS dan 1109'48,02" - 11058'37,40" BT. Memiliki potensi sumberdaya ikan yang cukup besar. Sumberdaya ikan tersebut terdapat di Laut Jawa yaitu sebelah barat dan utara wilayah Kabupaten Jepara, serta di perairan umum yang tersebar hampir di seluruh kecamatan di Kabupaten Jepara. Sebagian besar kecamatan di Kabupaten Jepara merupakan kecamatan pesisir yang memiliki beberapa pantai indah yang dijadikan sebagai objek wisata, di antaranya adalah Pantai Blebak yang terletak di Desa Sekuro dengan luas sekitar $537 \mathrm{Ha}$ dan panjang garis pantainya 2,40 km (Dinlutkan Kab. Jepara, 2014).

Pantai Blebak didominasi oleh mangrove, sehingga banyak biota laut yang berasosiasi dengannya termasuk moluska. Menurut Nontji (2007), salah satu kelompok fauna 
avertebrata sebagai penghuni ekosistem mangrove adalah filum moluska yang didominasi oleh gastropoda dan bivalvia. Gastropoda merupakan salah satu sumberdaya hayati non-ikan yang memiliki keanekaragaman tinggi pada ekosistem mangrove. Gastropoda berasosiasi pada ekosistem mangrove sebagai habitat yaitu tempat berlindung, memijah dan daerah mencari makan untuk kelangsungan hidupnya.

Gastropoda banyak dikenal dengan sebutan siput atau keong, memiliki bentuk dan ukuran yang bervariasi. Gastropoda memiliki nilai ekonomis penting sebab cangkangnya dapat digunakan untuk berbagai macam hiasan atau cinderamata dan dagingnya sebagai sumber bahan makanan. Menurut Rusyana (2011), gastropoda merupakan kelas Mollusca yang terbesar dan populer. Sekitar 50.000 spesies gastropoda masih hidup dan 15.000 jenis telah menjadi fosil. Oleh karena banyaknya gastropoda, maka hewan ini mudah sekali ditemukan.

Mengingat pentingnya peranan gastropoda dalam rantai makanan terhadap organisme-organisme yang hidup di dalam ekosistem pesisir, serta kurangnya informasi tentang keberadaan gastropoda di Pantai Blebak Jepara, maka perlu dilakukan penelitian tentang kelimpahan dan pola sebaran gastropoda di pantai Blebak Jepara. Tujuan dari penelitian ini adalah untuk mengetahui karakteristik dan mempelajari kelimpahan serta pola sebaran gastropoda di perairan Pantai Blebak Jepara.

\section{Bahan dan metode}

\subsection{Waktu dan tempat}

Penelitian ini dilaksanakan selama 5 (lima) bulan yaitu mulai bulan Juni sampai dengan bulan Oktober 2016. Lokasi penelitian di Pantai Blebak Desa Sekuro Kecamatan Mlonggo Kabupaten Jepara (Gambar 1).

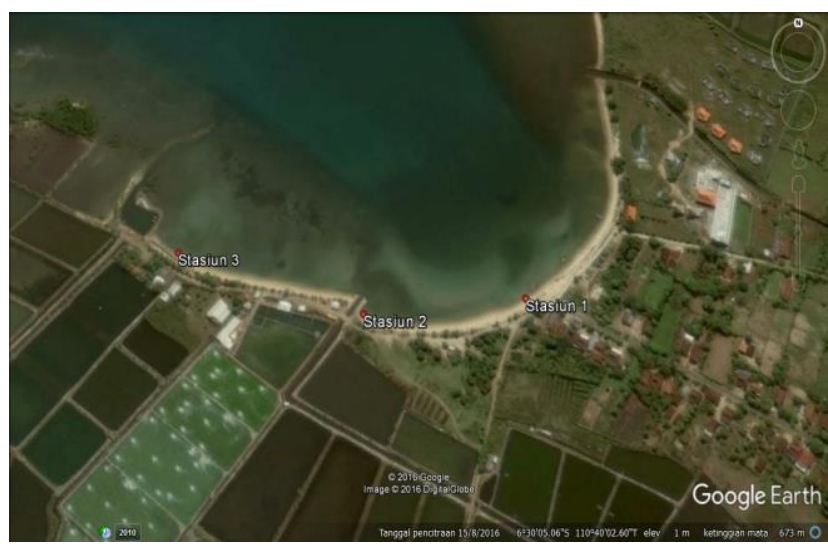

Gambar 1. Peta lokasi penelitian.

\subsection{Bahan dan alat}

Alat dan bahan yang digunakan selama penelitian disajikan pada Tabel 1.

\subsection{Sampling}

Teknik pengambilan sampel adalah purposive sampling. Pengambilan sampel gastropoda dilakukan pada setiap plot kuadrat $(1 \times 1) \mathrm{m}^{2}$ di setiap titik sampling yang telah ditentukan, yaitu stasiun $1\left(6^{\circ} 30^{\prime} 11,29^{\prime \prime}\right.$ LS dan $110^{\circ} 40^{\prime} 20,34$ BT), stasiun 2 $\left(6^{\circ} 30^{\prime} 11,77^{\prime \prime}\right.$ LS dan $110^{\circ} 40^{\prime} 14,94$ BT) dan stasiun 3 (6 $6^{\circ} 30^{\prime} 9,82^{\prime \prime}$ LS dan $110^{\circ} 40^{\prime} 8,55$ BT). Sampel diambil dari 3 stasiun yang berbeda yaitu stasiun 1 (dekat dengan tepi pantai), stasiun 2 (dekat dengan outlet tambak udang), dan stasiun 3 (dekat dengan mangrove). Masing-masing stasiun dibuat 1 garis transek sepanjang $30 \mathrm{~m}$ dengan jarak antar transek $10 \mathrm{~m}$ (Gambar 2).

Tabel 1.

Alat dan bahan yang diguanakan

\begin{tabular}{cll}
\hline No. & \multicolumn{1}{c}{ Alat dan bahan } & \multicolumn{1}{c}{ Kegunaan } \\
\hline 1. & Penggaris & Mengukur objek penelitian \\
2. & Termometer & Mengukur suhu perairan \\
3. & Refraktometer & Mengukur salinitas \\
4. & pH Stick & Mengukur pH perairan \\
5. & Transek Kuadrat $1 \mathrm{~m}^{2}$ & Sampling \\
6. & Roll meter & Penentuan panjang transek \\
7. & Tali raffia & Penanda luas stasiun \\
8. & Sechi disk & Mengukur kecerahan \\
9. & Kantong plastik & Tempat sampel \\
10. & Botol DO & Tempat sampel air luat \\
11. & Botol specimen & Tempat sampel yang sudah \\
& & diawetkan \\
12. & Buku identifikasi gastropoda & Mengidentifikasi jenis gastropoda \\
13. & Kamera digital & Dokumentasi \\
14. & Literatur-literatur yang & Data sekunder \\
& mendukung penelitian & \\
15. & Alkohol 70\% & Mengawetkan sampel \\
16. & Gastopoda & Objek Penelitian \\
\hline
\end{tabular}

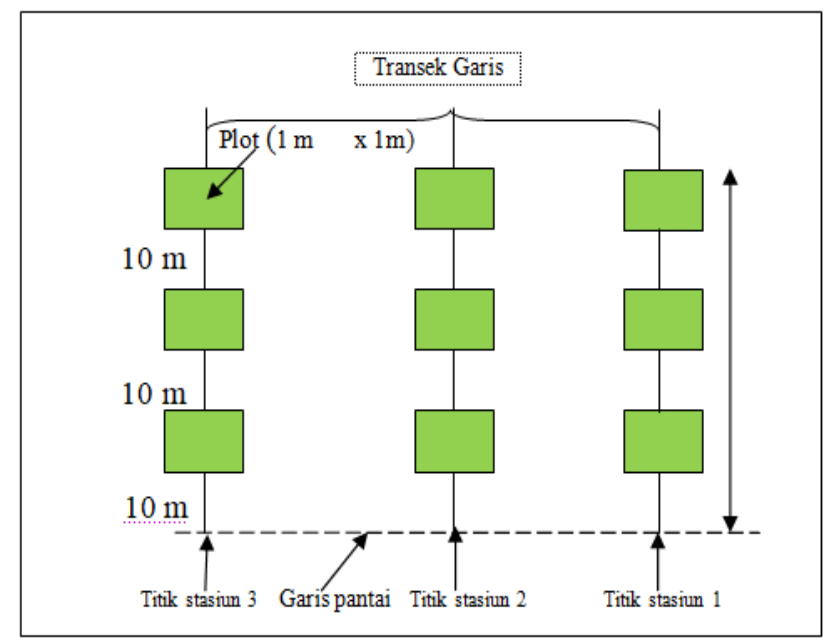

Gambar 2. Pemetaan peletakan garis transek Pantai Blebak.

Menurut Yusron (2013), pengambilan sampe menggunakan transek, dengan menempatkan tiga garis transek ke arah laut dan pada masing-masing garis transek dibagi menjadi tiga bagian, yaitu intertidal atas, tengah, dan bawah. Setiap garis transek diletakkan masing-masing tiga plot kuadrat berukuran $1 \mathrm{~m}^{2}$ di masing-masing intertidal.

Pengambilan sampel gastropoda dilakukan pada saat surut dan tidak hujan. Gastropoda yang diambil adalah gastropoda yang terdapat pada setiap plot kuadrat dan di dalam substrat sampai kedalaman $5 \mathrm{~cm}$. Gastropoda yang berada pada permukaan substrat maupun yang berada di dalam substrat diambil dengan cara mengambil semua substrat dengan bantuan sekop dan ember plastik. Selanjutnya sampel substrat yang diperoleh diayak dengan ayakan yang mempunyai mesh size 1 $\mathrm{mm}^{2}$ untuk memisahkan gastropoda dengan substrat. Bersamaan dengan pengambilan sampel biota dilaksanakan pengukuran parameter lingkungan perairan yaitu salinitas, suhu, kecerahan, kedalaman, kecepatan arus, $\mathrm{pH}$, oksigen terlarut (DO) dan sedimen.

Sampel gastropoda yang didapat selanjutnya dibersihkan dari kotoran, kemudian dimasukkan ke dalam botol sampel dan diawetkan dengan larutan alkohol $70 \%$. Buku identifikasi untuk sampel gastropoda yang digunakan adalah Oemarjati dan Wardhana, (1990) serta buku identifikasi FAO. 


\subsection{Analisis data}

Analisis data yang digunakan adalah kelimpahan dan pola sebaran gastropoda dengan menggunakan rumus. Kelimpahan suatu gastropoda dinyatakan sebagai jumlah individu/area. Menurut Odum (1993) dalam Silaen et al. (2013) rumus kelimpahan adalah sebagai berikut:

$$
\mathrm{A}=\mathrm{Xi} / \mathrm{ni}
$$

Keterangan:

$$
\begin{array}{ll}
\mathrm{A} & =\text { Kelimpahan (individu } / \mathrm{m}^{2} \text { ) } \\
\mathrm{Xi} & =\text { Jumlah individu dari jenis ke-i (individu) } \\
\mathrm{ni} & =\text { Luasan plot jenis ke-i ditemukan }\left(\mathrm{m}^{2}\right)
\end{array}
$$

Pola sebaran gastropoda dihitung dengan metode perhitungan dengan rumus Morisita (Krebs, 1989) dalam (Silaen et al., 2013) sebagai berikut:

\section{Keterangan:}

$$
\mathrm{Id}=\mathrm{n} \frac{\left(\sum \mathrm{X}^{2}-\mathrm{N}\right)}{\mathrm{N}(\mathrm{N}-1)}
$$

Id $\quad=$ Indeks Dispersi Morisita

$\mathrm{n} \quad=$ Jumlah total unit sampling/plot

$\mathrm{N}$ = Jumlah total individu yang terdapat dalam $\mathrm{n}$ plot

$\Sigma X^{2}=$ Kuadrat jumlah individu per plot

Dengan kriteria:

Id = 1 = Menunjukkan pola sebaran random atau acak ( $R)$

Id $>1$ = Menunjukkan pola sebaran clumped atau mengelompok (C)

Id $<1$ = Menunjukkan pola sebaran uniform teratur (U)

\section{Hasil dan pembahasan}

\subsection{Karakteristik kimia dan fisika perairan}

\begin{tabular}{|c|c|c|c|c|}
\hline No. & $\begin{array}{l}\text { Parameter } \\
\text { lingkungan }\end{array}$ & Stasiun 1 & Stasiun 2 & Stasiun 3 \\
\hline & Fisika & & & \\
\hline 1 & Suhu perairan $\left({ }^{\circ} \mathrm{C}\right)$ & 32 & 32 & 33 \\
\hline 2 & $\begin{array}{l}\text { Kecepatan arus } \\
(\mathrm{m} / \mathrm{s})\end{array}$ & 0,101 & 0,040 & 0,057 \\
\hline 3 & Kecerahan $(\mathrm{cm})$ & $\sim$ & $\sim$ & $\sim$ \\
\hline 4 & $\begin{array}{l}\text { Kedalaman }(\mathrm{cm}) \\
\text { Kimia }\end{array}$ & 136 & 71 & 62 \\
\hline 5 & $\mathrm{Ph}$ & 8 & 8 & 8 \\
\hline 6 & Do (mg/l) & 8,21 & 9,14 & 8,38 \\
\hline 7 & Salinitas (\%०) & 26 & 31 & 31 \\
\hline
\end{tabular}

Hasil pengukuran parameter fisika kimia perairan Pantai Blebak dapat dilihat pada tabel 2.

Tabel 2.

Karakteristik fisika dan kimia perairan Pantai Blebak

Suhu perairan di Pantai Blebak mempunyai kisaran antara $32-33^{\circ} \mathrm{C}$. Suhu tertinggi pada stasiun 3 yaitu $33^{\circ} \mathrm{C}$, sedangkan suhu terendah terdapat pada stasiun 1 dan 2 yaitu $32^{\circ} \mathrm{C}$. Pada stasiun 3 suhu air merupakan yang tertinggi diantara yang lain dikarenakan pada saat mengukur suhu air dilakukan pada siang hari pukul 11.00 WIB. Kisaran nilai suhu ini masih tergolong baik bagi kehidupan gastropoda, akan tetapi jika lebih dari $40^{\circ} \mathrm{C}$ dapat menyebabkan kematian pada semua jenis biota air (Nybakken, 1992).

Kecepatan arus yang terukur berkisar antara 0,040 $0,101 \mathrm{~m} / \mathrm{s}$. Arus ini terbilang cukup tenang. Kecepatan arus pada Stasiun 2 relatif lebih rendah dari stasiun lainnya. Selain itu, kecerahan perairan di lokasi penelitian yaitu tak hingga ( ), dikarenakan pada saat sampling pada siang hari dan dasar perairan masih terlihat dan cuacanya pun cerah. Kedalaman perairan di daerah pengamatan berkisar antara $62-136 \mathrm{~cm}$, yang dimana pengambilan sampel dilakukan sampai 30 meter dari pinggir pantai. Ini menandakan topografi pantai di pulau ini yang landai. Kedalaman perairan diukur pada saat perairan dalam keadaan surut yang bertujuan agar perhitungan dan pengamatan spesies gastropoda mudah dilakukan.

Nilai salinitas di Pantai Blebak berkisar antara 26-31\%。. Salinitas terendah terdapat pada Stasiun 1, yaitu $26 \%$. Salinitas tertinggi terdapat pada Stasiun 1 yaitu $31 \%$. Menurut Nontji (2007) bahwa salinitas diperairan berkisar antara $24 \%$ sampa $35 \%$. Sebaran salinitas dilaut dipengaruhi oleh berbagai faktor seperti pola sirkulasi air, penguapan, curah hujan dan aliran sungai.

Nilai derajat keasaman $(\mathrm{pH})$ di lokasi pengamatan adalah 8. Nilai tersebut memperlihatkan bahwa $\mathrm{pH}$ perairan bersifat basa dan termasuk normal untuk pH air laut di Indonesia. Hutabarat dan Evans (2000) menyatakan bahwa pH air normal adalah 7,2-8,1. pH air yang demikian masih layak untuk semua kebutuhan hidup. Gastropoda umumnya memerlukan $\mathrm{pH}$ antara $6,5-8,5$ untuk kelangsungan hidup dan reproduksi. Pada kondisi perairan yang alami, pH berkisar antara 4,0-9,0 (Gufran et al., 2007). Selanjutnya ditambahkan bahwa $\mathrm{pH}$ yang baik untuk kehidupan organisme laut adalah berkisar antara 6,5-9,0 dan kisaran optimal $\mathrm{pH}$ adalah 7,5-8,7.

Berdasarkan Tabel 2. diketahui bahwa hasil pengukuran konsentrasi oksigen terlarut pada ketiga stasiun berkisar antara 8,21 - 9,14 mg/l dengan rata-rata sebesar $8,58 \mathrm{mg} / \mathrm{l}$. Berdasarkan KEPMEN LH No. 51 (2004), setandar baku oksigen terlarut untuk kehidupan biota laut adalah $>5 \mathrm{mg} / \mathrm{l}$. Sehingga dikatakan keadaan oksigen terlarut pada ketiga stasiun baik dan normal.

\subsection{Tipe sedimen perairan}

Sedimen di perairan Pantai Blebak terdiri dari atas tiga tipe yaitu substrat pasir berpecahan cangkang, pecahan karang berpasir dan pasir berpecahan karang. Menurut Arbi (2012) menyebutkan bahwa gastropoda lebih menyukai jenis substrat pasir halus bahkan lumpur untuk hidup. Hal ini berkaitan dengan makan dan dimakan, dimana hampir semua jenis gastropoda memiliki sifat sebagai penyaring makanan (filter feeder). Penyaringan makanan dari substrat lebih sering terjadi pada substrat yang memiliki tekstur yang halus, sedangkan substrat yang memiliki tektur yang kasar lebih sulit bagi gastropoda untuk menyaring makanan. Tipe sedimen dari ketiga stasiun yang didapatkan pada setiap stasiun di perairan Pantai Blebak tersaji dalam Tabel 3.

\subsection{Kelimpahan gastropoda}

Berdasarkan hasil penelitian yang diamati di perairan Pantai Blebak Desa Sekuro Jepara, diperoleh 4 famili dari 7 spesies gastropoda yaitu Cerithidea cingulata, Cerithidea qudrata, Terebralis sulcata, Chicoreus capucinus, Littoraria scabra, Littoraria melanostoma, Volema paradisiacal. Dapat dilihat pada Tabel 4.

Nilai kelimpahan rata-rata gastropoda di perairan Panta Blebak jenis terbanyak Cerithidea qudrata yaitu 12,33 individu $/ \mathrm{m}^{2}$ sedangkan terbanyak kedua adalah Terebralis sulcata dengan kelimpahan 10,67 individu/ $\mathrm{m}^{2}$. 
Tabel 3.

Tipe sedimen di Perairan Pantai Blebak.

\begin{tabular}{|c|c|c|c|c|c|c|c|c|c|}
\hline \multirow{2}{*}{$\begin{array}{l}\text { Size } \\
(\mathrm{mm})\end{array}$} & \multicolumn{3}{|c|}{ Stasiun 1} & \multicolumn{3}{|c|}{ Stasiun 2} & \multicolumn{3}{|c|}{ Stasiun 3} \\
\hline & Berat (gr) & Persentase (\%) & Komposisi & Berat (gr) & Persentase (\%) & Komposisi & Berat (gr) & Persentase (\%) & Komposisi \\
\hline 4,75 & 7,6 & 1,52 & cangkang gastropoda & 185 & 37 & pecahan karang & 30 & 15 & pecahan karang \\
\hline 2,38 & 3,8 & 0,76 & pecahan cangkang & 38 & 7,6 & pecahan karang & 4 & 2 & pecahan karang \\
\hline 1,18 & 5,7 & 1,14 & pecahan cangkang & 25 & 5 & pecahan karang & 7 & 3,5 & pecahan karang \\
\hline 0,6 & 46 & 9,2 & pasir & 49 & 9,8 & pasir & 26 & 13 & pasir \\
\hline 0,3 & 158 & 31,6 & pasir & 97 & 19,4 & pasir & 41 & 20,5 & pasir \\
\hline 0,25 & 193 & 38,6 & pasir & 33 & 6,6 & pasir & 36 & 18 & pasir \\
\hline 0,15 & 84 & 16,8 & pasir & 53 & 10,6 & pasir & 43 & 21,5 & pasir \\
\hline 0,075 & 1,9 & 0,38 & pasir & 20 & 4 & pasir & 13 & 6,5 & pasir \\
\hline Tipe sedimen & \multicolumn{3}{|c|}{ Pasir berpecahan cangkang } & \multicolumn{3}{|c|}{ Pecahan karang berpasir } & \multicolumn{3}{|c|}{ Pasir berpecahan karang } \\
\hline
\end{tabular}

Tabel 4.

Jenis dan nilai kelimpahan rata-rata gastropoda (ind $/ \mathrm{m}^{2}$ ) di Perairan Pantai Blebak.

\begin{tabular}{lcccc}
\hline \multirow{2}{*}{ Spesies gastropoda } & \multicolumn{3}{c}{ Stasiun } & Rata-rata \\
\cline { 2 - 5 } & $\mathrm{I}$ & $\mathrm{II}$ & $\mathrm{III}$ & (ind $/ \mathrm{m}^{2}$ ) \\
\hline Famili Potamididae & 15 & 29 & 28 & 24 \\
$\begin{array}{l}\text { Cerithidea cingulata } \\
\text { Cerithidea qudrata }\end{array}$ & 13 & 13 & 11 & 12,33 \\
$\begin{array}{l}\text { Terebralis sulcata } \\
\text { Famili Muricidae }\end{array}$ & 10 & 14 & 8 & 10,67 \\
$\begin{array}{l}\text { Chicoreus capucinus } \\
\text { Famili Littorinidae }\end{array}$ & 1 & 2 & 0 & 1 \\
$\begin{array}{l}\text { Littoraria scabra } \\
\text { Littoraria melanostoma }\end{array}$ & 1 & 1 & 0 & 0,67 \\
Famili melongenidae & 4 & 0 & 1 & 1,67 \\
Volema paradisiaca & 4 & 3 & 1 & 2,67 \\
\hline Total & 48 & 62 & 49 & \\
\hline
\end{tabular}

\subsubsection{Stasiun I}

Tabel 5.

Kelimpahan gastropoda pada stasiun I disajikan pada

Tabel 5.

Kelimpahan gastropoda pada stasiun I.

\begin{tabular}{lccc}
\hline \multicolumn{1}{c}{ Spesies gastropoda } & Jumlah & Kelimpahan $/ \mathrm{m}^{2}$ & $\%$ \\
\hline Famili Potamididae & & & \\
$\begin{array}{l}\text { Cerithidea cingulata } \\
\text { Cerithidea qudrata }\end{array}$ & 15 & 0,50 & 31,25 \\
$\begin{array}{l}\text { Terebralis sulcata } \\
\text { Famili Muricidae }\end{array}$ & 13 & 0,43 & 27,08 \\
$\begin{array}{l}\text { Chicoreus capucinus } \\
\text { Famili Littorinidae }\end{array}$ & 10 & 0,33 & 20,83 \\
$\begin{array}{l}\text { Littoraria melanostoma } \\
\text { Littoraria melanostoma }\end{array}$ & 1 & 0,03 & 2,08 \\
$\begin{array}{l}\text { Famili Melongenidae } \\
\text { Volema paradisiaca }\end{array}$ & 1 & 0,03 & 2,08 \\
\hline \multicolumn{1}{c}{ Total } & 4 & 0,13 & 8,33 \\
\hline
\end{tabular}

Pada Stasiun I didapati 7 jenis gastropoda. Jenis terbanyak adalah Cerithidea cingulata dengan jumlah total 15 individu (31,25\%) dan kelimpahan 0,50 individu $/ \mathrm{m}^{2}$. Jenis terbanyak kedua adalah Cerithidea qudrata dengan jumlah total 13 individu $(27,08 \%)$ dan kelimpahan 0,43 individu $/ \mathrm{m}^{2}$. Jumlah total gastropoda yang ditemukan sebanyak 48 indivdu dengan kelimpahan total gastropoda pada Stasiun I sebesar 1,60 individu $/ \mathrm{m}^{2}$. Komposisi jenis gastropoda pada Stasiun I disajikan pada Gambar 3.

\subsubsection{Stasiun II}

Kelimpahan gastropoda pada Stasiun II disajikan pada Tabel 6. Pada Stasiun II didapati 6 jenis gastropoda. Jenis terbanyak adalah Cerithidea cingulata dengan jumlah total 29 individu $(46,77 \%)$ dan kelimpahan 0,97 individu $/ \mathrm{m}^{2}$. Jenis terbanyak kedua adalah Terebralis sulcata dengan jumlah total
14 individu (22,58\%) dan kelimpahan 0,47 individu $/ \mathrm{m}^{2}$. Jumlah total gastropoda yang ditemukan sebanyak 62 indivdu dengan kelimpahan total gastropoda pada Stasiun II sebesar 2,07 individu $/ \mathrm{m}^{2}$. Komposisi jenis gastropoda pada Stasiun II disajikan pada Gambar 4.

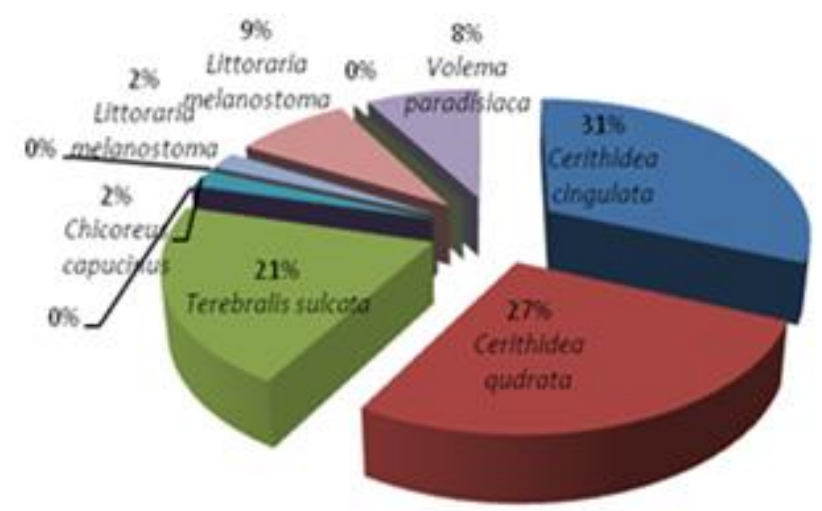

Gambar 3. Komposisi jenis gastropoda pada stasiun I.

Tabel 6.

Kelimpahan gastropoda pada stasiun II.

\begin{tabular}{lccc}
\hline \multicolumn{1}{c}{ Spesies gastropoda } & Jumlah & Kelimpahan $/ \mathrm{m}^{2}$ & $\%$ \\
\hline Famili Potamididae & & & \\
$\begin{array}{l}\text { Cerithidea cingulata } \\
\text { Cerithidea qudrata }\end{array}$ & 29 & 0,97 & 46,77 \\
$\begin{array}{l}\text { Terebralis sulcata } \\
\text { Famili Muricidae } \\
\text { Chicoreus capucinus }\end{array}$ & 13 & 0,43 & 20,97 \\
$\begin{array}{l}\text { Famili Littorinidae } \\
\text { Littoraria melanostoma }\end{array}$ & 14 & 0,47 & 22,58 \\
$\begin{array}{l}\text { Famili Melongenidae } \\
\text { Volema paradisiaca }\end{array}$ & 1 & 0,07 & 3,23 \\
\hline \multicolumn{1}{c}{ Total } & 3 & 0,03 & 1,61 \\
\hline & 62 & 0,10 & 4,84 \\
\hline
\end{tabular}

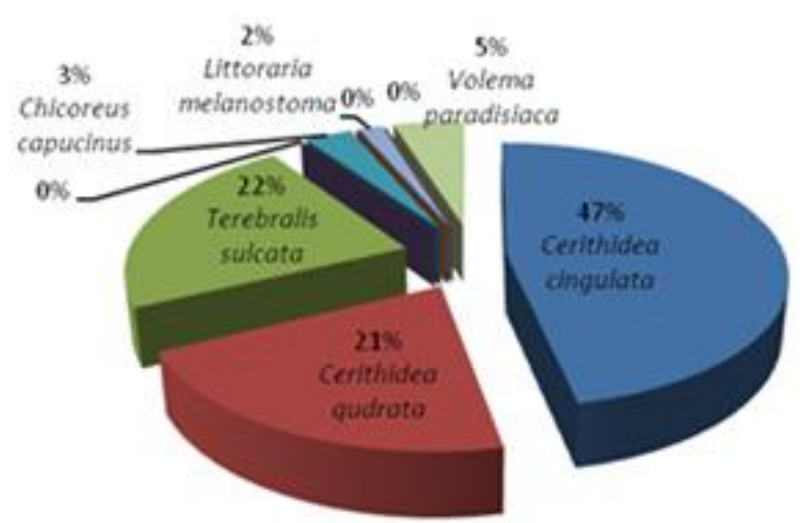

Gambar 4. Komposisi jenis gastropoda pada stasiun II 


\subsubsection{Stasiun III}

Kelimpahan gastropoda pada Stasiun III disajikan pada Tabel 7. Pada Stasiun III didapati 5 jenis gastropoda. Jenis terbanyak adalah Cerithidea cingulata dengan jumlah total 28 individu $(57,14 \%)$ dan kelimpahan 0,93 individu $/ \mathrm{m}^{2}$.

Tabel 7.

Kelimpahan gastropoda pada stasiun III

\begin{tabular}{lccc}
\hline \multicolumn{1}{c}{ Spesies gastropoda } & Jumlah & Kelimpahan $/ \mathrm{m}^{2}$ & $\%$ \\
\hline Famili Potamididae & 28 & & \\
$\begin{array}{l}\text { Cerithidea cingulata } \\
\text { Cerithidea qudrata }\end{array}$ & 11 & 0,93 & 57,14 \\
$\begin{array}{l}\text { Terebralis sulcata } \\
\text { Famili Littorinidae }\end{array}$ & 8 & 0,27 & 22,45 \\
$\begin{array}{l}\text { Littoraria melanostoma } \\
\text { Famili Melongenidae }\end{array}$ & 1 & 0,03 & 16,33 \\
Volema paradisiaca & 1 & 0,03 & 2,04 \\
\hline \multicolumn{1}{c}{ Total } & 49 & 1,63 & 2,04 \\
\hline
\end{tabular}

Jenis terbanyak kedua adalah Cerithidea qudrata dengan jumlah total 11 individu (22,45\%) dan kelimpahan 0,37 individu $/ \mathrm{m}^{2}$. Jumlah total gastropoda yang ditemukan sebanyak 49 indivdu dengan kelimpahan total gastropoda pada Stasiun III sebesar 1,63 individu $/ \mathrm{m}^{2}$. Komposisi jenis gastropoda pada Stasiun III disajikan pada Gambar 5.

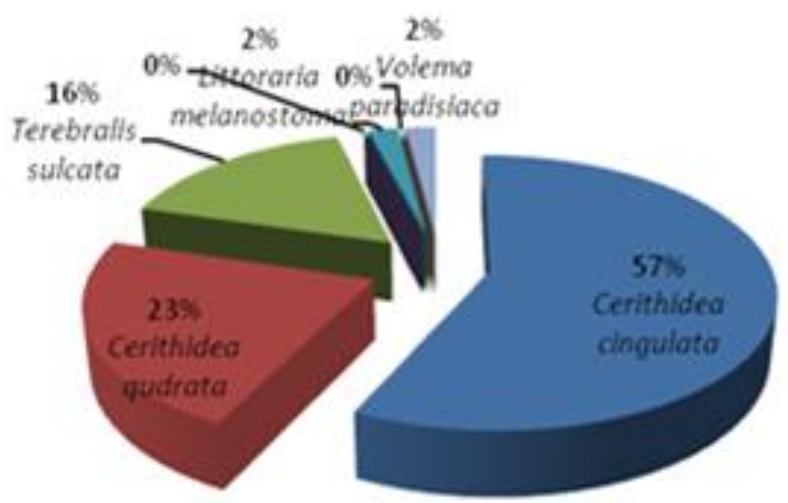

Gambar 5. Komposisi jenis gastropoda pada stasiun III

\subsection{Pola sebaran gastropoda}

Hasil penelitian menunjukkan bahwa pola sebaran gastropoda di Pantai Blebak Desa Sekuro lebih cenderung uniform teratur (U). Pola sebaran gastropoda dapat dilihat pada Tabel 8.

Tabel 8.

Pola sebaran gastropoda di Perairan Pantai Blebak.

\begin{tabular}{|c|c|c|c|c|c|c|}
\hline \multirow{2}{*}{ Spesies gastropoda } & \multicolumn{5}{|c|}{ Stasiun } & \\
\hline & \multicolumn{2}{|l|}{1} & \multicolumn{2}{|l|}{ II } & \multicolumn{2}{|l|}{ III } \\
\hline & $\overline{x i}$ & $x i^{2}$ & $x i$ & $x i^{2}$ & $x i$ & $x i^{2}$ \\
\hline \multicolumn{7}{|l|}{ Famili Ppotamididae } \\
\hline Cerithidea cingulata & 15 & 225 & 29 & 841 & 28 & 784 \\
\hline Cerithidea qudrata & 13 & 169 & 13 & 169 & 11 & 121 \\
\hline Terebralis sulcata & 10 & 100 & 14 & 196 & 8 & 64 \\
\hline \multicolumn{7}{|l|}{ Famili Muricidae } \\
\hline Chicoreus capucinus & 1 & 1 & 2 & 4 & 0 & 0 \\
\hline \multicolumn{7}{|l|}{ Famili Littorinidae } \\
\hline Littoraria scabra & 1 & 1 & 1 & 1 & 0 & 0 \\
\hline $\begin{array}{l}\text { Littoraria } \\
\text { melanostoma }\end{array}$ & 4 & 16 & 0 & 0 & 1 & 1 \\
\hline \multicolumn{7}{|l|}{ Famili Melongenidae } \\
\hline Volema paradisiaca & 4 & 16 & 3 & 9 & 1 & 1 \\
\hline $\mathrm{Ni}$ & 48 & & 62 & & 49 & \\
\hline $\mathrm{Ni}-1$ & 47 & & 61 & & 48 & \\
\hline$\Sigma x^{2}-N i$ & 480 & & 1158 & & 922 & \\
\hline $\mathrm{Ni}(\mathrm{Ni}-1)$ & 2256 & & 3782 & & 2352 & \\
\hline Id & 0,64 & & 0,92 & & 1,18 & \\
\hline
\end{tabular}

Hal ini terlihat pada Stasiun I dan II dengan nilai Indeks Morisita (Id) < 1. Pola sebaran merata ini menurut Odum (1993) terjadi karena adanya persaingan individu sehingga mendorong pembagian ruang secara merata. Namun untuk Stasiun III menunjukkan adanya pola sebaran clumped atau mengelompok (C) dengan nilai Indeks Morisita (Id) $>1$. Hal ini karena adanya pengumpulan individu sebagai startegi dalam menanggapi perubahan cuaca dan musim, serta perubahan habitat dan proses reproduksi (Odum, 1993).

\section{Kesimpulan}

Berdasarkan hasil penelitian dan analisis data terhadap kelimpahan dan pola sebaran gastropoda di perairan Panta Blebak Desa Blebak Kecamatan Mlonggo Kabupaten Jepara, dapat disimpulkan sebagai berikut:

1. Karakteristik gastropoda di Pantai Blebak Jepara adalah ditemukannya 4 famili dari 7 spesies Gastropoda yaitu Cerithidea cingulata, Cerithidea qudrata, Terebralis sulcata, Chicoreus capucinus, Littoraria scabra,Littoraria melanostoma, dan Volema paradisiaca.

2. Kelimpahan gastropoda di Pantai Blebak Jeparaadalah Cerithidea qudratamenunjukkan nilai kelimpahan tertinggi(12,33 individu/ $\left.\mathrm{m}^{2}\right)$.

3. Pola sebaran gastropoda di Pantai Blebak Jepara pada umumnya menyebar secara merata atau uniform teratur (U)

\section{Bibliografi}

Arbi, C. Y., 2012. Komunitas Moluska Di Padang Lamun Pantai Wori, Sulawesi Utara. Jurnal Bumi Lestari, 12(1): $55-65$

Dinas Kelautan dan Perikanan Kabupaten Jepara, 2014. Buku Profil Sektor Kelautan dan Perikanan Kabupaten Jepara 2014. Pemerintah Kabupaten Jepara Dinas Kelautan dan Perikanan. Jepara. 48 hal.

Nontji, A., 2007. Laut Nusantara. Penerbit Jambatan. Jakarta.

Nybakken, J., 1992. Biologi Laut: Suatu Pendekatan Ekologis. PT Gramedia Pustaka Utama. Jakarta.

Odum, E. P., 1993. Dasar-Dasar Ekologi. Yogyakarta: Gajah Mada University Press.

Oemarjati, B. S., Wardhana, W., 1990. Taksonomi Avertebrata: Pengantar Praktikum Laboratorium. UI-Press. Jakarta. 177 hal.

Rusyana, A., 2011. Zoologi Invertebrata (Teori dan Praktik). CV Alfabeta. Bandung. 282 hal.

Saripantung, L., Gladys, Tamanampo, J.F.W.S., Manu, G,. 2013. Struktur Komunitas Gastropoda di Hamparan Lamun Daerah Intertidal Kelurahan Tongkeina Kota Manado. Jurnal IImiah Platax. Vol. 1: (3). Hal $102-108$.

Sastrawijaya, A. T., 2000. Pencemaran Lingkungan. PT Rineka Cipta. Jakarta.

Silaen, I. F., Hendrarto, B., Supardjo, M.N., 2013. Distribusi dan Kelimpahan Gastropoda Pada Hutan Mangrove Teluk Awur. Journal of Management of Aquatic Resources. Vol. 2: (3). Hal $93-103$. 
Suwondo, E., Febrita, Sumanti, F., 2006. Struktur Komunitas Gastropoda Pada Hutan Mangrove di Pulau Sipora Kabupaten Kepulauan Mentawai Sumatera Barat. Jurnal Biogenesis. Vol. 2: (1). Hal 25-29.

Yusron, E., 2013. Biodiversitas Fauna Ekhinodermata (Holothuroidea, Echinoidea, Asteroidea, dan Ophiuroidea) di Perairan Pulau Lombok, Nusa Tenggara Barat. Jurnal Zoo Indonesia. Vol.22: (1). Hal 1-10. 